\title{
Pengembangan Desa melalui Optimalisasi Literasi, Pariwisata, Kesehatan, dan Sosial di Kecamatan Riung, Ngada, NTT
}

\author{
Syamsul Hadi i, ${ }^{1}$ Dody Ariawan' ${ }^{1}$ Zainal Arifin'1 ${ }^{\text {Muchlish }}{ }^{2} \mid$ Alfian $^{3}$ \\ ${ }^{1}$ Teknik Mesin, Fakultas Teknik, Universitas Sebelas Maret \\ ${ }^{2}$ Nangamese, Riung, Ngada, Nusa Tenggara Timur \\ ${ }^{2}$ Riung, Ngada, Nusa Tenggara Timur
}

\begin{abstract}
Abstrak
Kelurahan Nangamese merupakan salah satu Kelurahan di Kecamatan Riung Kabupaten Ngada Nusa Tenggara Timur dimana sebagian besar penduduknya merupakan nelayan. Bidang pendidikan yang masih terlambat karena terbatasnya sumber daya pengajar dan bidang pariwisata yang belum digali yang sehingga belum banyak dikenali oleh masyarakat di Indonesia meski banyak potensi wisata alam yang sangat indah merupakan permasalahan yang dihadapi oleh masyarakat Nangamese. Pelaksanaan Kuliah Kerja Nyata (KKN) di Kelurahan Nangamese ini bertujuan untuk memberikan informasi mengenai peningkatan dalam bidang pendidikan, pariwisata, kesehatan, dan sosial. Potensi wisata alam dapat dimanfaatkan sebagai penghasilan pendapatan masyarakat lokal dengan ditambah membuat produksi oleh-oleh agar semakin dikenal oleh masyarakat di Indonesia, dan dalam bidang pendidikan dapat mulai dikenalkan dengan bahasa asing sejak dini, bidang kesehatan yaitu melatih masyarakat setempat untuk menjadi kader kesehatan. Seluruh kegiatan yang diadakan oleh Tim KKN UNS di Kelurahan Nangamese disambut dan diikuti secara antusias oleh masyarakat yang ditunjukkan dengan semangat dari seluruh peserta yang mengikuti kegiatan. Kegiatan pada bidang pendidikan non-formal juga mendapat respon yang cukup positif dimana Tim KKN memberikan pendidikan dan keterampilan untuk siswa sekolah dasar penyuluhan dan pelatihan menanam tanaman vertikal dan kaderisasi kesehatan untuk ibu-ibu. Selain itu adapula kegiatan pekan kreativitas, bimbingan belajar, dan peringatan Hari Kemerdekaan Republik Indonesia yang diikuti sangat antusias oleh anak-anak di Kelurahan Nangamese. Dapat disimpulkan kegiatan KKN UNS di Kelurahan Nangamese terlaksana dengan baik. Seluruh rencana program kerja terlaksana dan direspon positif oleh masyarakat meskipun ada beberapa kendala yang dihadapi.
\end{abstract}

Kata kunci : KKN, pendidikan, pariwisata, kesehatan, sosial, Nangamese, Riung, Ngada

\section{Pendahuluan}

Kuliah Kerja Nyata $(\mathrm{KKN})$ merupakan upaya universitas untuk memberikan kesempatan mahasiswa untuk meningkatkan soft skillnya (Sunardhi, 2018) dengan hidup bersama masyarakat sehingga dapat membantu dan mendampingi masyarakat untuk menggali potensi sumber daya manusia dan alam yang ada sehingga dapat mengatasi permasalahan yang ada dan meningkatkan taraf hidup ke arah yang lebih baik (UNS, 2013). Dengan pariwisata sebagai leading sector dalam meraup devisa negara dan berbagai tujuan di atas, KKN di daerah lokasi wisata merupakan sesuatu hal yang menarik dikaji. Pariwisata yang merupakan perjalanan dari suatu tempat ke tempat lain, bersifat sementara, dilakukan perorangan maupun kelompok, sebagai usaha mencari keseimbangan atau keserasian dan kebahagiaan dengan lingkungan hidup dalam dimensi sosial, budaya, alam dan ilmu (Spilane,1987), maka pengembangan pariwisata termasuk juga pengusahaan obyek daya tarik wisata serta usaha-usaha yang terkait di bidang tersebut untuk menciptakan kembali kesegaran baik fisik maupun psikis agar dapat berprestasi lagi (Fandeli, 1995). Dikarenakan pariwisata merupakan suatu sektor yang kompleks, yang juga melibatkan industri-industri klasik seperti kerajinan tangan dan cinderamata, serta usaha-usaha penginapan,

Penulis Korespondensi. Email: syamsulhadi@ft.uns.ac.id 
restoran dan transportasi (Pendit, 1990) maka, pengembangan pariwisata memiliki tiga fungsi yaitu untuk menggalakkan ekonomi, memelihara kepribadian bangsa dan kelestarian fungsi dan mutu lingkungan hidup serta, memupuk rasa cinta tanah air dan bangsa (Joyosuharto, 1995). Dengan pentingnya dan kompleksnya permasalahan berkaitan dengan pariwisata maka diperlukan berbagai strategi pengembangan daerah wisata (Sefira dkk., 2013; Meiwany dkk., 2018; Soebagyo, 2012; dan Febrianti dkk., 2014)

Salah satu program dari universitas untuk memberikan kesempatan mahasiswa untuk meningkatkan soft skillnya adalah Kuliah Kerja Nyata (KKN) (Sunardhi, 2018) dengan hidup bersama masyarakat sehingga dapat membantu dan mendampingi masyarakat untuk menggali potensi sumber daya manusia dan alam yang ada sehingga dapat mengatasi permasalahan yang ada dan meningkatkan taraf hidup ke arah yang lebih baik (UNS, 2013). Sebagai salah satu lokasi KKN, desa Nangamese Riung merupakan objek yang menarik untuk dikaji. Karena Riung merupakan daerah pariwisata yang sudah terkenal ke mancanegara, wisatawan yang datang ke Riung biasanya berasal dari Negara Belanda, Perancis, Jerman dan masih banyak lagi. Jadi, bisa kita simpulkan bahwa Riung merupakan destinasi pariwisata tingkat Internasional. Sama seperti Labuan Bajo, Riung memiliki banyak sekali lokasi pariwisata, bahkan bisa dibilang sangat lengkap, contohnya di Riung memiliki Taman Wisata Alam Laut (TWAL 17 pulau), Semenanjung Torong Padang, Watu Wangka, Labuan Kelambu dan masih banyak lagi. Namun dari banyaknya lokasi-lokasi tersebut, hanya TWAL 17 pulau saja yang baru beroperasi menjadi tempat tujuan pariwisata. Bahkan di Riung sendiri memiliki komodo khas Riung, yang biasa kita sebut dengan Mbau. Ada banyak sekali yang bisa dieksplor di Riung, oleh karena itu program utama KKN adalah pariwisata karena masyarakat dan pemerintah Riung butuh perubahan di bidang pariwisata. Jika ditinjau dari potensinya, di Kelurahan Nangamese ini tidak hanya wisata 17 pulau saja yangindah namun masih terdapat banyak tempat wisata lain yang memiliki potensi untuk dimanfaatkan untuk sumber pendapatan masyarakat Kelurahan Nangamese. Potensi wisata alam tersebut dapat dibudidayakan, dikembangkan dan diolah kedalam wujud lain yang dapat dimanfaatkan warga desa serta dijual guna mendongkrak perekonomian warga Kelurahan Nangamese. Masyarakat Kelurahan Nangamese merupakan masyarakat yang membuka diri untuk mengembangkan dan memajukan desanya. Untuk itu, kegiatan KKN perlu dilakukan untuk melakukan pemetaan dan branding sehingga meningkatkan peran pariwisata dalam menggerakkan roda perekonomian di daerah tersebut.

\section{Metode Pelaksanaan}

Dari berbagai permasalahan yang ada di Kelurahan Nangamese, dilakukan beberapa kegiatan periode KKN UNS Juli-Agustus 2019 untuk mengurangi dampak permasalahan yang ada mulai dengan pemetaan data awal wilayah KKN dan pelaksanaan KKN dengan metode survey, sosialisai, pendampingan, kerja bersama, motivasi, penyuluhan dan monitoring. Metode yang dilakukan tersebut disesuaikan dengan potensi alam dan potensi manusia di Desa Nangamese. Khalayak sasaran kegiatan PPM Prioritas ini adalah pemuda pemudi, aparat desa, kelompok tani, ibu-ibu PKK, anak anak, kelompok wanita tani, dan masyarakat desa Nangamese yang mempunyai motivasi untuk pengembangan diri. Mahasiswa melaksanakan berbagai tahapan kegiatan selama 40 hari dan tinggal bersama masyarakat sehingga menyelami kebutuhan riel masyarakat. Tahapan pelaksanaan KKN tersebut dapat diuraikan dalam satu tema besar tentang pengembangan pariwisata yang terdiri dari beberapa kegiatan yaitu pemetaan wilayah pariwisata, pembuatan peta wisata, program Riung Ngopi, Program Riung Souvenir, Riung Art Shop, dan kebersihan lokasi wisata. Untuk mendukung pengembangan pariwisata juga dilakukan pengembangan potensi warga dan anak anak dengan pendidikan bahasa asing dan budaya literasi serta bagi warga masyarakat lain diadakan kegiatan kesehatan dan budidaya sayuran di lahan sempit.

\section{Hasil dan Pembahasan}




\section{Hasil awal pemetaan wilayah dan potensi}

KKN Tematik Integratif bertema Pengembangan Desa Melalui Optimalisasi Literasi, Pariwisata, Kesehatan, dan Sosial dilaksanakan di Kelurahan Nangamese, Kecamatan Riung, Kabupaten Ngada, Nusa Tenggara Timur yang secara geografis berada pada koordinat antara $8^{\circ} 25^{\prime}-9^{\circ} 00^{\prime}$ LS dan $120^{\circ} 45^{\prime}$ - $121^{\circ} 50^{\prime}$ BT dengan wilayah utara Nangamese berbatasan dengan Laut Flores, sebelah barat berbatasan dengan Desa Golo Ite sedangkan untuk wilayah timur dan selatan bebatasan dengan Kelurahan Benteng Tengah. Kelurahan Nangemese merupakan salah satu dari 12 kelurahan/desa yang berada di Kecamatan Riung dimana masyarakat yang berkembang berasal dari beberapa wilayah di Indonesia. Kelurahan Nangamese sendiri terdiri dari lingkungan Nangamese, Punsu, dan Manoreng. Pusat administrasi kelurahan Nangamese berada di lingkungan Punsu. Berdasarkan sejarah, Kelurahan Nangamese kebanyakan jumlah penduduknya bersuku daerah Flores. Masyarakat yang berada di bagian atas (gunung) didominasi masyarakat keturunan suku Flores. Sedangkan sebagian masyarakat yang berada di bawah atau sekitar pesisir (dermaga) merupakan keturunan suku Bugis. Kelurahan Nangamese merupakan wilayah yang strategis, dimana beberapa kantor perangkat pemerintahan tingkat kecamatan berdiri di wilayah ini. Segala administrasi dan pelayanan kependudukan kecamatan Riung berada di kelurahan Nangamese. Sementara itu, jumlah penduduk di kecamatan Riung tidak terlalu padat, terdiri dari 13.916 jiwa dengan luas daerah $103,19 \mathrm{Km}^{2}$.

Wilayah Kelurahan Nangamese memiliki potensi alam dan pariwisata yang luar biasa dan mulai dikenal di kancah mancanegara. Selain itu, kelurahan Nangamese terletak di ujung utara pulau Flores dan memiliki Taman Laut yang dikenal dengan Taman Laut 17 Pulau Riung. Serta berada di wilayah pesisir sehingga sebagian masyarakatnya bermatapencaharian sebagai nelayan. Banyak masyarakat yang bergerak di sektor pariwisata, seperti menyediakan hotel/penginapan, restaurant/cafe, tour guide dan persewaan boat mengingat adanya Taman Laut 17 Pulau Riung yang sangat potensial sebagai penggerak ekonomi di Nangamese. Wisatawan mancanegara lebih mendominasi kunjungan ke Taman Laut 17 Pulau Riung. Sementara itu, masyarakat yang berada di atas (lingkungan Punsu, Manoreng, bagian atas) bermatapencaharian tenaga administrasi pemerintahan, guru, tenaga medis, dan sebagainya. Secara umum, masyarakat Nangamese memiliki kualitas ekonomi yang cukup memadai, mengingat hasil alam yang melimpah dan pariwisata yang mendukung untuk meningkatkan taraf perekonomian keluarga.

Pendidikan di Kelurahan Nangamese masih dibilang kurang. Dalam ketersediaan prasarana di masingmasing sekolah dapat dikatakan masih belum lengkap. Keadaan beberapa kelas masih belum layak karena keadaan sarana dalam kelas seperti meja dan kursi banyak yang rusak. Sarana penunjang dalam kegiatan pembelajaran seperti peta, globe, papan tulis, dan lainnya masih belum lengkap sehingga kurang mendukung kegiatan belajar mengajar. Sebagian besar masyarakat di Kelurahan Nangamese sebenarnya sudah menyadari pentingnya pendidikan yaitu wajib belajar 12 tahun (sampai tingkat SMA/SMU), namun mereka hanya berhenti menempuh pendidikan sampai tingkat SMA/SMU. Hal ini dikarenakan, mereka terhambat oleh biaya sehingga tidak mampu meneruskan pendidikan di Perguruan Tinggi.

Dalam bidang keagamaan, mayoritas penduduk Kelurahan Nangamese memeluk agama Islam dan sebagian kecil memeluk agama kristen. Walaupun terdapat perbedaan agama, akan tetapi mereka mampu hidup rukun, saling beriringan dan menghormati. Bahkan banyak sekali kegiatan keagamaan di setiap dusun untuk meningkatkan keimanan dan ketaqwaan serta silaturahmi antar warga Kelurahan Nangamese. Karang Taruna masing-masing dusun sudah aktif berjalan dan mengadakan beberapa kegiatan yang melibatkan masyarakat seperti lomba dalam rangka HUT RI, tirakatan, arisan pemuda, kerja baktir, dan pertemuan rutin setiap satu bulan sekali. Sehingga sarana komunikasi antar warga Desa Puhgogor dapat berjalan efektif. Untuk bidang agama dan sosial budaya, pada dasarnya tidak ada permasalahan yang serius dalam kehidupan bermasyarakat di Kelurahan Nangamese. Masyarakat hidup berdampingan dengan penuh toleransi di tengah perbedaan yang ada. Wilayah Nangamese di daerah pesisir banyak dihuni oleh masyarakat Suku Bugis yang mayoritas memeluk agama Islam, sedangkan 
wilayah yang lain banyak dihuni oleh masyarakat lokal dan menganut agama Nasrani. Selain itu, banyak masyarakat pendatang yang berasal dari Pulau Jawa. Masyarakat saling menghargai perbedaan agama dan kebudayaan yang dianut.

Keadaan sarana prasarana di Kelurahan Nangamese dapat dikategorikan baik jika dibandingkan dengan kelurahan/desa lain di Kecamatan Riung. Banyak fasilitas umum yang berdiri di Nangamese, antara lain Kantor Kecamatan Riung, bank, Kantor Cabang Sub Wilayah PLN, pasar Riung dan Balai Konservasi Sumber Daya Alam (BKSDA). Akan tetapi, terkait dengan ketersediaan air di beberapa rumah yang menggunakan layanan dari PDAM, masyarakat mengalami sedikit permasalahan, seperti sedikitnya air yang mengalir bahkan air tidak dapat keluar sama sekali selama beberapa hari. Selain itu terkadang air masih bercampur dengan sedikit kapur.

Kondisi kesehatan di wilayah Nangamese tergolong baik dan tidak ditemukan penyakit endemis. Pihak Puskesmas Riung dan instansi terkait senantiasa melaksanakan program-program kesehatan untuk meningkatkan kualitas kesehatan di wilayah Kecamatan Riung pada umumnya. Akan tetapi, kurangnya kesadaran masyarakat dalam menjaga kondisi kesehatan dan rasa enggan untuk mengikuti pemeriksaan kesehatan masih menjadi hambatan dalam mewujudkan upaya peningkatan kualitas kesehatan tersebut. Selain masalah kesehatan yang masih terdapat hambatan, kebersihan di lingkungan Nangamese juga masih ditemukan berbagai macam permasalahan. Banyak sampah berceceran di pinggir jalan karena tidak adanya tempat sampah yang tersedia. Selain itu, kebiasaan warga setempat untuk membakar sampah menimbulkan terjadinya polusi udara. Hal ini dikarenakan di Kecamatan Riung sendiri tidak terdapat TPA sehingga tidak ada alur pembuangan sampah yang sistematis seperti pembuangan sampah di kota pada umumnya.

Wilayah Nangamese merupakan wilayah yang menjadi kantor pusat di kecamatan Riung. Akses administrasi kelurahan mudah dijangkau karena berada di wilayah strategis. Namun, administrasi di kelurahan Nangamese masih sederhana. Pengelolaan administrasi, pembukuan keuangan, dan pengelolaan inventaris kelurahan masih kurang memadai dan sedikit mengalami permasalahan sehingga perlu adanya sosialisasi dan pengarahan dari instansi atas yang terkait. Dari segi pemerintahan desa, perangkat kelurahan Nangamese terdiri dari lurah, sekretaris desa, bendahara desa, 3 pembantu kelurahan dan 4 kepala lingkungan. Keadaan pemerintahan cukup baik. Namun partisipasi perangkat desa, pejabat lain ataupun masyarakat dalam bermusyawarah/rapat, kegiatan gotong-royong atau kegiatan bersama lain masih kurang. Seringkali banyak ketidakhadiran peserta rapat dari jumlah surat undangan yang tersebar. Hal tersebut dikarenakan masih mementingkan kepentingan sendiri atau pekerjaan yang lebih penting dari pada ikut serta dalam rapat di kelurahan.

Perekonomian di Nangamese secara umum sudah cukup baik. Masyarakat sekitar pantai bermatapencaharian sebagai nelayan dan memanfaatkan perahunya di sektor pariwisata. Banyak masyarakat setempat yang ikut andil dalam bidang pariwisata yang berkembang. Akan tetapi, pengelolaan pariwisata dirasa masih kurang. Padahal, Nangamese memiliki potensi yang besar untuk memeroleh manfaat ekonomi lebih dari adanya Taman Wisata Alam 17 Pulau. Banyak pebisnis yang masih bergerak secara individu dalam menjalankan usahanya dalam penyediaan fasilitas wisata. Selain itu, masyarakat setempat masih kurang memanfaatkan peluang usaha yang semestinya dapat dilakukan. Banyak masyarakat pendatang yang berprofesi sebagai pedagang memanfaatkan potensi pemasaran yang ada di Riung. Hal ini perlu menjadi perhatian pemerintah dan masyarakat setempat agar roda perekonomian di Nangamese dapat bergerak lebih baik dengan memanfaatkan seluruh potensi yang ada. Sarana dan prasarana berkaitan dengan bidang pariwisata sendiri masih dirasa kurang mengingat Nangamese memiliki dermaga yang menjadi akses utama menuju Taman Wisata Alam 17 Pulau. Kondisi dermaga telah mengalami kerusakan di beberapa titik. Selain itu, kondisi bangunan loket belum maksimal. Keadaan kamar mandi bilas yang berada di pulau juga kurang mendapat perawatan sehingga manfaat yang diperoleh wisatawan menjadi kurang. 
Program Pemetaan Potensi Wisata Riung merupakan kegiatan observasi dan survei ke setiap lokasi yang memiliki potensi untuk dikembangkan lebih lanjut sebagai objek wisata alam. Program pemetaan potensi wisata Riung dirasa perlu dilakukan karena kondisi wisata Riung yang sedang sangat berkembang. Berkembangnya wisata di Riung dipengaruhi oleh lokasinya yang dekat dengan objek wisata lain seperti Labuan Bajo dan Danau Kelimutu. Saat ini, Kecamatan Riung sudah sering dikunjungi oleh wisatawan, terutama wisatawan asing. Namun, wisatawan tersebut umumnya hanya mengunjungi satu tempat wisata, yaitu Taman Wisata Alam Laut 17 Pulau Riung, dan kemudian melanjutkan ke tempat wisata lainnya seperti Bajawa atau Labuan Bajo. Padahal Kecamatan Riung masih memiliki masih banyak potensi objek wisata yang belum disadari oleh warga sekitar maupun pemerintah.

Langkah awal dalam penggalian potensi tersebut yaitu dengan melakukaan pemetaan lokasi yang memiliki potensi wisata. Untuk menemukan lokasi-lokasi yang berpotensi untuk dijadikan objek wisata, dilakukan pengumpulan informasi dari tokoh masyarakat dan warga sekitar. Kemudian dilakukan observasi dan survei menuju lokasi-lokasi tersebut. Untuk mengetahui lokasi objek berpotensi wisata di dalam peta menggunakan aplikasi GPS. Hasil dari survei dan observasi berupa informasi tertulis, peta, dan dokumentasi yang telah didapat akan kemudian diolah menjadi peta tematik objek wisata Riung. Meski proses pemetaan terkendala oleh cuaca, waktu, dan akses yang sulit untuk menuju lokasi serta pemetaan dengan menggunakan GPS menjadi kurang akurat akibat tidak adanya jaringan di lokasilokasi tertentu tetapi program pemetaan potensi wisata Riung berupa peta tematik yang berisikan informasi-informasi yang telah didapat. Peta yang telah dicetak kemudian diletakkan di dermaga Nangamese yang juga menjadi pintu masuk untuk menuju Taman Wisata Alam Laut 17 Pulau Riung. Peletakan tersebut untuk mempermudah wisatawan maupun warga sekitar untuk melihat peta. Diharapkan wisatawan yang melihat akan berkeinginan untuk mengunjungi objek-objek wisata yang berada di dalam peta. Sedangkan bagi masyarakat sekitar agar menyadari potensi wisata yang selama ini dimiliki oleh Kecamatan Riung dan kemudian dapat dikembangkan untuk meningkatkan perekonomian warga sekitar objek wisata. Selain itu, peta tematik tersebut dapat menjadi acuan untuk asosiasi pariwisata yang ada dalam pengembangan pariwisata lebih lanjut. Setelah pemetaan selesai dilakukan, dibuat kegiatan Riung Ngopi yang merupakan forum diskusi antar pemangku kepentingan pariwisata di Riung sehingga diperoleh kesepakatan untuk membentuk ASPANA (Asosiasi Pariwisata Nangamese) sebagai pengelola segala bidang pariwisata, juga merancang DEWI SARA (Desa Wisata Sambinasi Raya), sebagai tujuan utama pariwisata setelah TWAL 17 pulau serta terbentuknya rancangan GOALS RIUNG 2025.

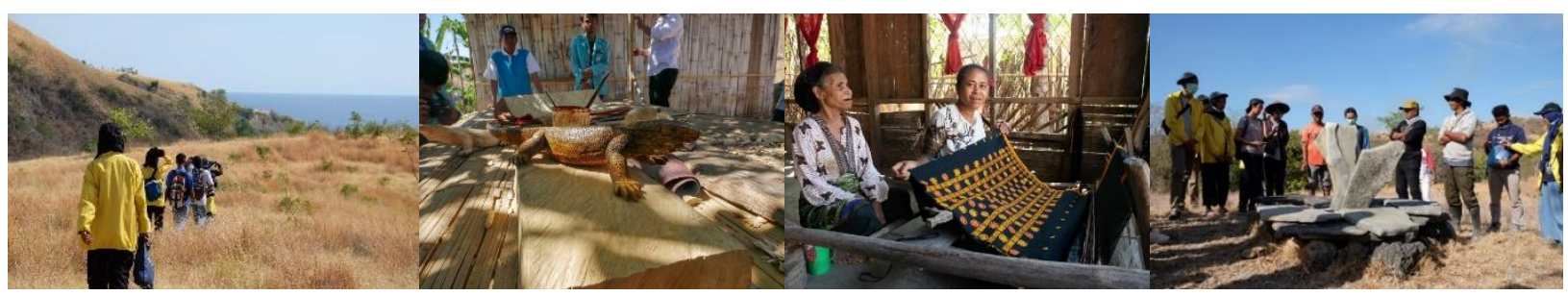

Gambar 1. Potensi wisata yang ada di Riung NTT

Disamping itu dilakukan kegiatan Program Riung Souvenir yang merupakan suatu program penyuluhan kepada pemuda di Kelurahan Nangamese agar mengetahui pentingnya penjualan souvenir di desa yang termasuk daerah pariwisata. Penjualan buah tangan atau souvenir penting karena untuk menambah kegiatan positif pemuda untuk mengisi waktu luang, untuk menambah penghasilan para pemuda dan membuat Riung mempunyai buah tangan khusus untuk para wisatawan yang hadir. Tidak hanya penyuluhan saja dalam program Riung Souvenir ini tetapi disini juga ada pelatihan serta pembuatan buah tangan yang penjualannya melalui paket tour yang diadakan pemuda sebagai guide lokal atau bisa menunjang program "Riung Makmur". Hasil yang dicapai dari program ini adalah Meningkatnya kesadaran dan pengetahuan masyarakat tentang pentingnya kerajinan tangan yang membantu pariwisata dalam bidang ekonomi. Tindak lanjut dari program ini pemuda bisa selanjutnya mengisi waktu luangnya 
untuk membuat souvenir untuk dijual di tempat penjualan souvenir (Art Shop) dalam Riung Makmur dan membuat Riung menjadi terkenang dengan sebuah souvenir bagi para wisatawan. Partisipasi masyarakat dalam kegiatan ini berjalan dengan baik. Masyarakat memberikan respon positif dengan membantu segala persiapan serta berlangsungnya acara dalam kegiatan ini dan memberikan antusiasme yang ditandai dalam diskusi tanya jawab dalam penyuluhan dan pemberian saran dalam apa saja yang ingin dibuat souvenir sebagai tambahan ide dari masyarakat sendiri dan pada saat pembuatan souvenir berlangsung para pemuda mengikuti dan menjalankannya dengan skill yang cukup tinggi dalam menggunakan alat pembuat souvenir dan telaten dalam pembuatan souvenir. Pemerintah daerah juga membantu dalam persiapan penyuluhan dengan meminjamkan barang-barang yang tersedia di Kecamatan dan proses peminjamannya juga dimudahkan. Program Art Shop merupakan program penunjang dari program Riung Ngopi dan diwujudkan dengan membangun Art Shop atau toko oleholeh khas kelurahan Nangamese. Art Shop dibangun karena Nangamese yang merupakan gerbang wisata Taman Laut 17 pulau namun sampai detik ini belum memiliki toko oleh-oleh. Toko ini menjual berbagai macam makanan, kerajinan, khas Kecamatan Riung. Dalam kegiatan ini mahasiswa KKN bekerja sama dengan pemuda desa untuk membangun toko oleh-oleh. Barang-barang yang dijual adalah hasil kerja tangan masyarakat yang tinggal di kelurahan Nangamese itu sendiri. Warga sekitar menyambut dengan sangat senang dengan adanya realisasi dari keinginan mereka untuk membangun toko oleh-oleh. Hasil yang dicapai dari program ini adalah telah berdiri toko oleh-oleh untuk menjual barang dan makanan khas kepada wisatawan yang dating ke Taman Wisata Air Laut 17 Pulau baik yang lokal maupun mancanegara. Tindak lanjut dari program ini ialah sebagai sarana lapangan pekerjaan baru untuk pemuda Kelurahan Nangamese untuk meneruskan penjualan di toko oleh-oleh.

Untuk mendukung kenyamanan turis selama berpariwisata maka dibutuhkan tempat wisata yang nyaman dan bersih. Untuk itu juga dilakukan program bersih sampah pulau yang merupakan kegiatan membersihkan sampah yang terdapat di Pulau Taor, Pulau Tiga, dan Pulau Rutong agar sampah tidak mengganggu ekosistem terutama sampah plastik. Hal ini dikarenakan sampah plastik sulit terurai dan apabila sampah plastik ini dibiarkan akan mengganggu ekosistem. Sampah plastik yang dikumpulkan ini nantinya akan digunakan untuk membuat ecobrick sehingga sampah yang tadinya tidak berguna justru dapat menghasilkan. Hasil yang dicapai dari program ini adalah pulau bersih dari sampah plastik baik sampah pengunjung maupun sampah bawaan air laut. Partisipasi masyarakat dalam kegiatan ini berjalan dengan cukup baik. Masyarakat memberikan respon positif terhadap kegiatan ini ditandai dengan tingginya antusiasme masyarakat yang ikut membersihkan sampah di pulau.

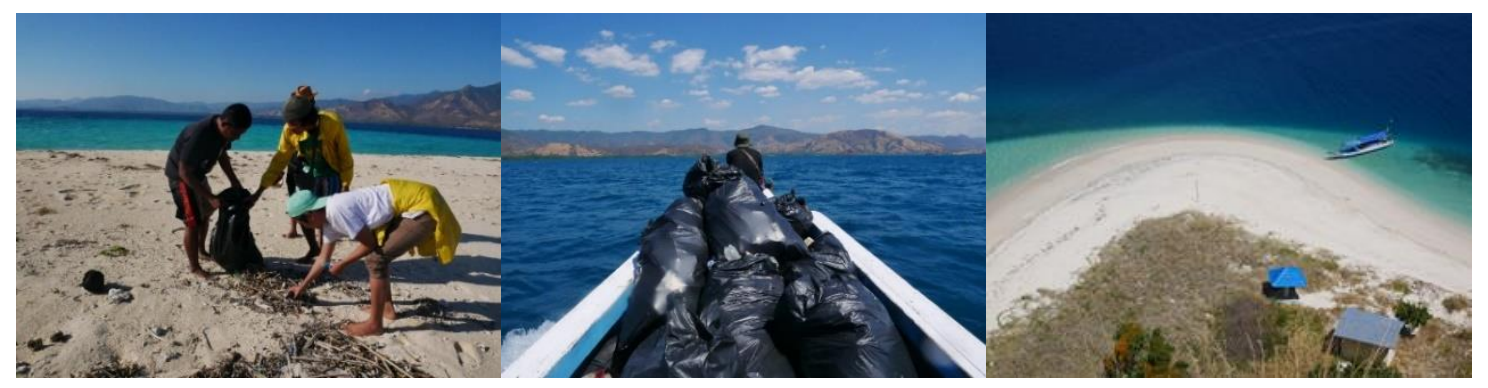

Gambar 2. Pengelolaan dan peningkatan kepedulian sampah di pantai Riung NTT

Di samping itu pasar wisata atau sering dikenal dengan sebutan pasar malam merupakan pasar yang diadakan di malam hari pada akhir pekan. Para penjual yang berjualan di pasar tersebut merupakan warga dari Kelurahan Nangamese. Produk yang dijual di pasar tersebut berupa makanan siap saji, seperti olahan hewan laut yang merupakan hasil tangkapan para nelayan, kue jajanan pasar, makanan tradisional, serta minuman tradisional daerah setempat. Pasar wisata tersebut terakhir diadakan yaitu lebih dari satu tahun yang lalu, yang kemudian berhenti akibat adanya faktor cuaca yang tidak mendukung yaitu musim penghujan. Namun ketika musim hujan tersebut berakhir, pasar wisata tidak berjalan seperti sebelumnya. Hal tersebut terjadi karena kurangnya minat masyarakat untuk memulai kembali. Sehingga program ini kami rancang sebagai awal untuk memulai kembali kegiatan pasar 
wisata atau pasar malam yang sempat berhenti. Kegiatan pasar wisata diadakan pada hari sabtu malam dan minggu malam. Hasil yang dicapai dari kegiatan ini yaitu dapat dimulai kembalinya pasar wisata yang sempat terhenti dalam selang waktu yang cukup lama. Tindak lanjut dari kegiatan ini yaitu pasar wisata dapat berjalan secara konsisten setiap pekannya. Masyarakat setempat mendukung diadakannya kembali pasar wisata karena kegiatan tersebut merupakan salah satu kegiatan yang dapat dijadikan waktu untuk berkumpul bersama seluruh warga. Peran instansi pemerintahaan yaitu memfasilitasi hiburan dan melakukan kegiatan promosi dengan cakupan wilayah yang luas. Kalendar budaya merupakan rangkuman kegiatan budaya selama 1 tahun dan dirangkum menjadi kalender budaya guna menunjang pariwisata Riung. Kumpulan budaya-budaya yang dirangkum menjadi kalender budaya untuk menunjang wisatawan mengetahui tentang budaya Riung,guna meningkatkan pariwisata di daerah tersebut.

Sebagai desa yang memiliki potensi di bidang pariwisata, bahasa Inggris sangat berguna. Penanaman bahasa Inggris sejak dini sangat penting sebagai bekal dalam menghadapi persaingan global dewasa ini. Namun salah satu permasalahan yang muncul di Kelurahan Nangamese ini adalah kurangnya guru bahasa Inggris di sekolah, sehigga siswa tidak mendapatan pendidikan bahasa Inggris yang memadai. Berdasarkan potensi desa yang dimiliki oleh Kelurahan Nangamese, ada beberapa program yang cocok untuk dilaksanakan di desa ini, salah satunya pelaksanaan pembelajaran bahasa Inggris yang menyenangkan. Kegiatan ini mendapat sambutan dan respons yang baik dari masyarakat Kelurahan Nangamese, hal ini terbukti dari banyak siswa yang antusias mengikuti kegiatan ini. Kegiatan ini berupa pemberian materi dasar-dasar bahasa Inggris seperti alfabet, angka, nama hari, bulan, nama anggota tubuh, nama-nama benda yang dekat dengan kehidupan sehari-hari peserta didik, dan memberikan informasi arah dan tujuan yang sering digunakan dalam kehidupan sehari-hari. Meskipun sarana dan prasarana di sekolah yang kurang memadai, kemampuan kognitif dari para siswa terbilang masih kurang, dan pengaturan waktu yang cukup singkat, tetapi hasil yang dicapai pada program kerja ini adalah para siswa SD/MI memahami materi dasar yang disampaikan mengenai alfabet, anggota tubuh, dan sebagainya. Untuk tingkat MTS, para siswa menjadi lebih memahami dan mampu mempraktikkan bahasa Inggris dalam kegiatan sehari-hari khususnya menginformasikan arah dan tujuan. Juga partisipasi dari para siswa dalam kegiatan ini berjalan dengan baik. Para siswa memberikan respons positif dengan adanya kegiatan ini, ditandai dengan antusiasme yang tinggi selama kegiatan berlangsung. Adanya dukungan penuh dari para guru di instansi-instansi terkait juga menjadi faktor penunjang kelancaran kegiatan ini, misalnya mengizinkan kegiatan ini berlangsung dan memberikan kewenangan kepada tim KKN untuk mengatur jadwal kegiatan di sekolah masing-masing.

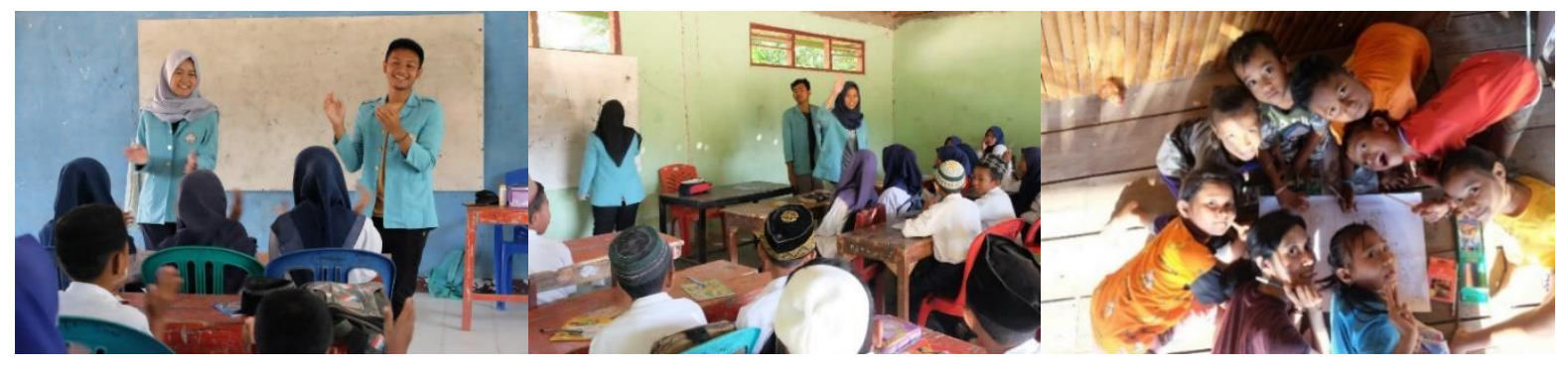

Gambar 3. Pekan kreativitas dan pembelajaran Bahasa Inggris di Riung NTT

Pekan Kreativitas merupakan program kerja utama Tim KKN UNS di Nangamese, Riung, Ngada, NTT. Program tersebut dipilih karena tema KKN di Kelurahan Nangamese adalah "Pengembangan Desa melalui Optimalisasi Pariwisata, Pendidikan, Kesehatan, dan Pemberdayaan Masyarakat" yang dibutuhkan oleh masyarakat terutama oleh anak-anak Sekolah Dasar. Pada umumnya anak-anak suka dengan hal yang baru dan mempunyai tingkat kreativitas yang tinggi sehingga kami mewadahi ide krativitas anak anak dengan program kreativitas yang ditujukan untuk mengembangkan dan meningkatkan ide kreativitas anak-anak di Nangamese, Riung, Ngada, NTT. Kegiatan ini dilaksanan di rumah inspirasi yang terletak di kelurahan Nangamese. Pada kegiatan ini anak-anak diajarkan untuk 
menggambar sesuai imajinasi anak-anak. Pelaksanaan program Pekan Kreativitas telah terlaksana dengan sangat memuaskan. Hal ini dikarenakan banyaknya dukungan positif yang kami dapat serta partisipasi dari anak-anak dalam menyambut baik kegiatan ini. Salah satu asosiasi yang bergerak dalam bidang literasi sangat membantu banyak dalam pelaksanaan program ini. Program tersebut dipilih karena literasi masih sangat dibutuhkan oleh masyarakat terutama oleh anak-anak Sekolah Dasar. Pada kebanyakan anak-anak yang ada, kegiatan membaca masih sangatlah terasa membosankan sehingga tak jarang anak-anak lebih memilih untuk bermain daripada membaca buku. Pada program ini kegiatan membaca buku dikemas menjadi lebih menyenangkan sehingga anak-anak tidak merasa bosan dan merasa seperti sedang bermain.

Tidak hanya membaca saja, anak-anak juga diajarkan untuk menceritakan kembali apa yang sudah mereka baca menggunakan media-media yang dapat mereka buat sendiri. Hal ini dapat memancing kreativitas pada diri anak-anak, juga dapat meningkatkan kepercayaan diri pada masing-masing anak. Hasil yang dicapai dalam program Pekan Literasi ini adalah meningkatnya minat baca pada anak-anak, selain itu anak-anak dapat menceritakan kembali atau mempresentasikan kembali apa yang telah mereka dapat melalui media-media yang telah disediakan. Pelaksanaan program Pekan Literasi telah terlaksana dengan sangat memuaskan. Hal ini dikarenakan banyaknya dukungan positif yang didapat serta partisipasi dari anak-anak dalam menyambut baik kegiatan ini. Bimbingan Belajar merupakan program tambahan belajar diluar jam sekolah bersifat non formal yang dilaksanakan oleh mahasisawa KKN di Kelurahan Nangamese. Pengadaan bimbingan belajar ini untuk kalangan peserta didik tingkat sekolah dasar atau SD, dan sekolah menengah pertama atau SMP. Diadakannya bimbingan belajar guna membantu peserta didik yang ada di Nangamese menyelesaikan tugas maupun melakukan pembelajaran ulang sesuai dengan materi yang telah disampaikan disekolahan. Kegiatan ini dilakukan untuk memotivasi para peserta didik untuk meningkatkan semangat untuk selalu belajar, rasa tanggung jawab, dan mandiri. Hasil yang dicapai dari kegiatan bimbingan belajar adalah bertambahnya pemahaman peserta didik mengenai pentingnya bimbingan belajar diluar sekolah sehingga bertambah bentuk kemandirian, rasa tanggung jawab terhadap tugas dan keseriusan dalam belajar. Tindak lanjut dari kegiatan bimbingan belajar adalah tetap diadakannya bimbingan belajar yang di dampingi oleh guru atau pendamping belajar yang menyenangkan. Pelaksanaan kegiatan bimbingan belajar yang dikemas dengan metode menyenangkan terlaksana dengan baik. Hal ini dikarenakan masyarakat, pihak sekolah dan juga peserta didik mempunyai respon yang baik terhadap kegiatan bimbingan belajar.

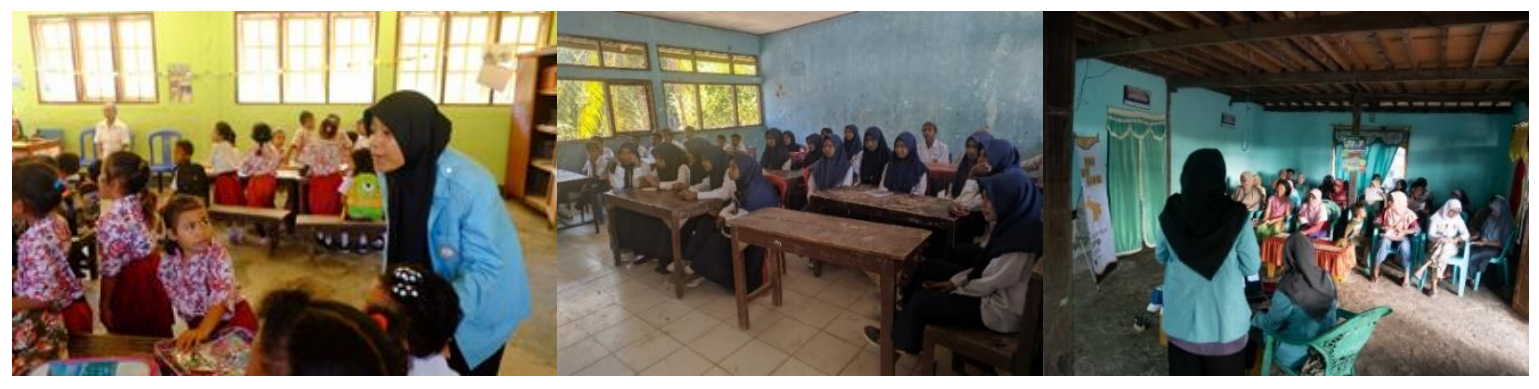

Gambar 4. Program vertikultur, pekan literasi, dan Bumil Care sebagai pemberdayaan masyarakat di Riung NTT

Program Bumil Care merupakan suatu program penyuluhan kepada ibu-ibu di Kelurahan Nangamese agar mengetahui pentingnya ASI dan MP-ASI sehingga diharapkan setelah diberikan penyuluhan para warga terutama ibu-ibu dapat memberikan ASI dan MP-ASI secara tepat. Dengan diberikan ASI dan MP-ASI secara tepat maka dapat membantu balita dalam pertumbuhan dan perkembangannya sehingga dapat mencegah adanya stunting pada balita, mengingat prevalensi stunting di provinsi NTT masih tergolong tinggi. Pemantauan pertumbuhan dan perkembangan sendiri dilakukan di Posyandu setempat, untuk itu guna mendukung adanya korelasi dari manfaat yang ingin dicapai program ini dilakukan beriringan dengan kegiatan posyandu yang dilaksanakan rutin setiap bulan. Program ini dilaksanakan disela sela kegiatan posyandu. Riung's Main Health Cadre adalah program kerja yang disusun 
berdasarkan pengamatan dan data kesehatan warga Nangamese, dan tema yang diambil adalah mengenai hipertensi. Kelurahan Nangamese terletak di pinggir laut, sehingga mayoritas pekerjaan warga adalah melaut. Makanan yang sering dikonsumsi adalah hasil laut seperti ikan, kerang, siput, kepiting dan lain-lain yang mana makanan tersebut tinggi natrium dan kolesterol. Dalam kegiatan ini dilakukan penyuluhan tentang hipertensi dan diajarkan kepada ibu-ibu khususnya kader untuk belajar melakukan pengukuran tensi. Tujuannya adalah mengontrol tekanan darah warga Nangamese, mengingat begitu penting dan berisikonya tekanan darah tinggi yang tidak terkontrol. Selain itu agar warga Nangamese tidak perlu jauh-jauh ke Puskesmas untuk mengecek tekanan darah, karena selain diajarkan juga diberikan alat tensi dan stetoskop kepada kader sehingga warga dapat mengontrol tekanan darah dengan datang ke posyandu rutin yang diadakan kader paham dan bisa melakukan pengukuran tekanan darah warga dengan benar. Saat posyandu, kegiatan posyandu dapat ditambah dengan cek tensi secara rutin tiap bulannya (sebelumnya hanya penimbangan berat badan dan tinggi badan bayi balita). Masyarakat sangat antusias dalam kegiatan ini. Kegiatan juga berjalan dengan baik karena dukungan dari pihak kecamatan dengan meminjamkan proyektor dan LCD demi keberlangsungan acara ini.

Program Vertikultur di Timur merupakan salah satu teknik bercocok tanam yang dilakukan secara vertikal untuk memanfaatkan lahan sempit (seperti pekarangan/halaman rumah) dan memenuhi estetika rumah. Program ini awalnya ditujukan untuk istri nelayan di Kelurahan Nangamese dengan harapan meningkatnya perekonomian keluarga, namun dikarenakan kesibukan keluarga terhadap pekerjaan kaitannya dengan nelayan dan mengantar turis asing maupun lokal, membuat sasaran program ini dialihkan kepada anak-anak. Program budidaya tanaman sayur juga sudah pernah dicoba oleh suatu komunitas kepada tiap keluarga di Kelurahan Nangamese dengan adanya pembagian polybag dan benih gratis, namun minat masyarakat untuk berbudidaya tanaman masih rendah dan polybag justru terbengkalai. Anak-anak dijadikan sebagai sasaran baru dari kegiatan program ini dengan tujuan menanamkan dan menumbuhkan rasa cinta lingkungan sejak dini dan memperkenalkan tentang jenis tanaman hortikultura dengan cara yang menyenangkan yaitu belajar sekaligus bermain. Wadah yang digunakan untuk bertanam yaitu botol plastik bekas. Tujuan penggunaan botol plastik bekas merupakan salah satu bagian dari pengurangan sampah plastik yang banyak dihasilkan masyarakat Kelurahan Nangamese khususnya dari hotel-hotel wisatawan yang ada. Media tanam menggunakan campuran tanah dan pupuk organik dengan perbandingan 1:1. Benih yang digunakan adalah benih bayam dan benih kangkung sebagai bagian dari tanaman hortikutura. Penambahan perlengkapan yaitu cat supaya anak-anak lebih antusias dan bersemangat dalam mengikuti kegiatan. Hasil yang dicapai dari program ini adalah bertambahnya pengetahuan anak-anak Kelurahan Nangamese tentang tanaman hortikultura dan bagaimana cara mengaplikasikannya. Selain itu juga menumbuhkan kemauan anak-anak untuk bertanam sejak dini. Tindak lanjut dari program ini yaitu anak-anak didukung orang tua dapat menanam sayur di rumah masing-masing dengan adanya pembagian benih untuk dibawa pulang.

\section{Kesimpulan dan Saran}

Dari uraian yang telah dipaparkan di atas tentang serangkaian kegiatan selama KKN, ada hal-hal yang dapat dijadikan kesimpulan diantaranya KKN merupakan salah satu bentuk pengabdian kepada masyarakat yang eksistensinya masih sangat dibutuhkan. Hal ini terlihat dari tingginya antuasiasme masyarakat yang menginginkan masukan untuk pembangunan di Kelurahan Nangamese, Riung, Flores, NTT dan masyarakat sangat mendukung program-program yang dibawakan. Berbagai masukan, pandangan dan harapan disampaikan oleh warga demi kemajuan desa, di mana fokus yang diharapkan oleh masyarakat adalah terciptanya kemajuan desa. Di samping itu hasil kegiatan KKN ini dapat dinikmati lewat laman https://www.youtube.com/watch? $\mathrm{v}=6 \mathrm{P} 9$ Uimbks00\&feature=youtu.be dan buku di https://isbn.perpusnas.go.id/Account/SearchBuku?searchCat=ISBN\&searchTxt=978-623-7266-709.

Kegiatan KKN ini sangat bermanfaat baik untuk mahasiswa ataupun masyarakat namun akan lebih baik 
jika kegiatan tersebut ditindaklanjuti dengan program yang bersifat berkelanjutan seperti pemetaan dengan menggunakan teknologi drone sehingga potensi wisata dapat tergambarkan dengan lebih jelas dan dapat di upload di website2 pariwisata sehingga meningkatkan kepopuleran Riung di mata dunia dan meningkatkan jumlah dan lama tinggal wisatawan yang datang. Juga data yang dikumpulkan selama KKN mestinya lebih detil sehingga dapat ditindaklanjuti dengan kegiatan yang lebih rinci ke depannya dan keberhasilan program KKN dapat terukur lebih mudah dan tepat.

\section{Ucapan Terima Kasih}

Kegiatan pengabdian pada masyarakat ini merupakan program KKN UNS yang dibiayai dengan dana PNBP UNS tahun 2019. Ucapan terima kasih disampaikan kepada bapak Muchlis selaku sesepuh di desa Nangamese dan bapak Alfian, S. Sos. selaku Camat Riung yang telah mambantu kegiatan KKN dan juga kepada anggota tim KKN yaitu Rahman Malik Azis, Ade Lella Wahyuning F, Titania Aurera Larasati, Bethari Santun Selasih, Warimah, Rizqi Abdurrozzaq, Ni'mah Nilna Fauzia, Akbar Muhammad, KT. Dewi Hajar Fraidee Laras, Fauzi Ahmad Rahman, Furqon Aji Nugroho, Sasha Geganaresi Liardi, Isnaini Asmara, Pipiet Endwiyatni, Tria Ramadhanti Monats, Dyah Ayu Widyati, dan Wiwit Reza Algiyanto.

\section{Referensi}

Fandeli, Chafid. (1995), Pengertian dan Kerangka Dasar Kepariwisataan dalam "Dasar-dasar manajemen Kepariwisataan Alam". Editor: Chafid Fandeli, Liberty, Yogyakarta

Febrianti Dwi Cahya Nurhadi, Mardiyono, dan Stefanus Pani Rengu. (2014). Strategi Pengembangan Pariwisata Oleh Pemerintah Daerah Terhadap Pendapatan Asli Daerah (Studi pada Dinas Pemuda, Olahraga, Kebudayaan dan Pariwisata Kabupaten Mojokero). Jurnal Administrasi Publik (JAP), Vol. 2, No. 2, 325-331

Joyosuharto, S. (2000). Aspek Ketersediaan dan Tuntutan Kebutuhan Dalam Pariwisata, dalam "DasarDasar Manajemen Kepariwisataan Alam, Editor: Ch. Fandeli, Liberty, Yogyakarta

Meiwany A. K. Tapatfeto dan Juita L.D Bessie. (2018). Srategi Pengembangan Objek Wisata Dalam Upaya Peningkatan Kunjungan (Studi Pada Objek Wisata Pantai Oetune Kabupaten TTS). Journal of Management (SME's), Vol. 6, No.1, 1-20

Pendit, Ny. S. (1990), Ilmu Pariwisata, Sebuah Pengatar Perdana. PT Pradnya Paramita, Jakarta Sefira

Ryalita Primadany, Mardiyono, dan Riyanto. (2013). Analisis Strategi Pengembangan

Pariwisata Daerah (Studi pada Dinas Kebudayaan dan Pariwisata Daerah Kabupaten Nganjuk). Jurnal Administrasi Publik (JAP) Brawijaya, Vol. 1, No. 4, 135-143

Soebagyo. (2012). Strategi Pengembangan Pariwisata di Indonesia. Jurnal Liquidity, Vol. 1, No. 2 , $153-158$

Spilane, JJ., (1987), Pariwisata Indonesia, Sejarah dan Prospeknya, Kanisius, Yogyakarta

Sunardi W. (2018) Pembelajaran Mahasiswa KKN Terintegrasi PPM Universitas Padjadjaran Dalam Menyampaikan Prototipe Hasil Penelitian Program Academic Leadership Grant Kepada Masyarakat Pengguna dan Calon Pengguna, Jurnal Pengabdian kepada Masyarakat Unpad, Vol 2 No 9. pp. 780-783

Universitas Sebelas Maret (UNS). (2013). Pedoman Penyelenggaraan Kuliah Kerja Nyata Universitas Sebelas Maret, SK Rektor 579/UN27/PP.2013 